\title{
WPLYW FINANSYZACJI NA ROZWÓJ RYNKU FINANSOWEGO NA PRZYKŁADZIE PRODUKTÓW STRUKTURYZOWANYCH W POLSCE W LATACH 2006-2016
}

\begin{abstract}
Celem niniejszego opracowania jest scharakteryzowanie finansyzacji, ale także ukazanie wpływu na rozwój rynku finansowego na przykładzie produktów strukturyzowanych jako innowacyjnych instrumentów finansowych w Polsce w latach 2009-2016. Chociaż w czasopiśmiennictwie nie pomija się warunków politycznych, kulturowych i społecznych leżących u podstaw finansjalizacji przedsiębiorstw, to w dominującej na ten temat literaturze anglosaskiej uwaga skupiana jest przede wszystkim na opisywaniu ścisłego związku między aktywnością inwestorów instytucjonalnych i skalą akumulacji finansowej. Wykazano przede wszystkim, że wzrost stopnia finansjalizacji jest powiązany ze zjawiskiem presji ,niecierpliwych" inwestorów instytucjonalnych, bardziej zainteresowanych krótkoterminowymi zyskami spółek i ich bieżącą konsumpcją niż oczekiwaniem na osiągnięcie przez nie lepszych wyników z działalności gospodarczej w długim okresie, implikowanych efektywną alokacją kapitału wewnętrznego. Zjawisko to traktowane jest również jako główny czynnik napędowy tendencji do poszukiwania maksymalnej stopy zwrotu z zainwestowanego kapitału przy jak najmniejszym ryzyku, co tym samym stanowi fundamentalny imperatyw koncepcji SHV. Finansyzacja rozumiana jako dominacja sektora finansowego nad sektorem realnym, co jest najbardziej widoczne w USA, była jedną z istotnych przyczyn globalnego kryzysu finansowego. Autorka w oparciu o polską i zagraniczną literaturę przedmiotu oraz dane statystyczne przedstawia główne przyczyny, natężenie i skutki finansyzacji na rynku finansowym w Polsce. Biorąc to pod uwagę, należy stwierdzić, że w tym kontekście zasadne jest nie tylko badanie samego zjawiska finansjalizacji, ale także poszukiwanie odpowiedzi na pytanie o kierunki przemian zachodzące na rynkach finansowych.
\end{abstract}

Słowa kluczowe: finansyzacja, produkty strukturyzowane, instrumenty finansowe, rynek finansowy.

\footnotetext{
${ }^{1}$ Dr Elżbieta Ważna, Instytut Ekonomii i Zarządzania, Zakład Rachunkowości i Finansów, Państwowa Wyższa Szkoła Techniczno-Ekonomiczna im. ks. Bronisława Markiewicza w Jarosławiu, ul. Czarnieckiego 16, 37-500 Jarosław; tel. 1662446 48; e-mail: ela.wazna@op.pl.

Elżbieta Ważna, PhD, State Higher School of Technology and Economics in Jarosław, Czarnieckiego 16, 37-500 Jarosław; mobile: 00481662446 48, Institute of Economics and Management; mail: ela.wazna@op.pl.
} 


\section{WSTĘP}

Ostateczne zerwanie więzi światowego pieniądza z kruszcem, jakie nastąpiło na początku lat 70. XX w., doprowadziło do finansyzacji gospodarki światowej². Pod tym pojęciem kryje się przerost rynków oraz instytucji finansowych w relacji do potencjału sfery realnej, który zaburza jej funkcjonowanie w skali poszczególnych krajów, regionów, a nawet - globalnej. Do końca XX w. hipertrofia sektora finansowego występowała przede wszystkim w krajach o dojrzałych rynkach finansowych. Obecnie proces ten zaczął dotyczyć również grupy rynków wschodzących, które stwarzają dogodne możliwości elastycznego kształtowania struktury posiadanych aktywów, zgodnie z preferencjami poszczególnych podmiotów do ponoszenia akceptowalnego poziomu ryzyka ${ }^{3}$.

Tak trudno sobie wyobrazić przeprowadzanie istotnej transakcji finansowej (nie tylko pomiędzy partnerami biznesowymi) bez udziału pośredniczącej instytucji finansowej. Podobnie jest w całej sferze finansowej e-biznesu, w której po najostrzejszym kryzysie od 1980 r. obserwuje się rozwój wszelkiego rodzaju instrumentów finansowych i rozliczeniowych ${ }^{4}$. Najszybszy rozwój szerokiej grupy instrumentów finansowych dotyczył instrumentów pochodnych (derywatów, derivatives). Upowszechnienie instrumentów pochodnych pozwoliło instytucjom finansowym na wprowadzenie kolejnej nowości, czyli produktów strukturyzowanych. Z punktu widzenia wystawcy stanowią one złożenie instrumentu dłużnego z instrumentem pochodnym. Dla nabywcy są odpowiednikiem lokaty z obietnicą potencjału znacznego zysku. Rzadko jednak nabywca zdaje sobie sprawę z różnorodności ryzyka związanego z produktem strukturyzowanym, zwłaszcza gdy jest to instrument oferowany posiadający ,pełną ochronę kapitału”.

Finansyzacja ma także swoje źródło w gwałtownym rozwoju rynków finansowych zwłaszcza od drugiej połowy XX wieku. W krajach wysoko rozwiniętych, chociaż przesłanki i niektóre przejawy wystąpiły już w okresie wcześniejszym. P.M. Sweezy w końcu lat 90. nazwał ,finansyzacją" proces akumulacji kapitału, który jest główną siłą ,,ciągnącą" wzrost gospodarczy od lat 70. XX wieku'. Aby podkreślić skalę rozwoju rynków finansowych wystarczy zauważyć, że jeszcze w roku 1980 podstawowe aktywa finansowe (depozyty zgromadzone w bankach, wyemitowane przez różne podmioty obligacje i akcje) stanowiły około $120 \%$ globalnego $\mathrm{PKB}^{7}$, a już w 2007 roku aktywa te wraz z instrumentami pochodnymi (tymi ostatnimi ujętymi według wartości nominalnej) wynosiły aż

2 M. Husson, Kapitalizm bez znieczulenia, Warszawa 2011, s. 224-225.

3 T. Waściński, G. Wójcik, Struktura rynku finansowego w gospodarce światowej, Zeszyty Naukowe Uniwersytetu Przyrodniczo-Humanistycznego, nr 88, Seria Administracja i Zarządzanie (15), Siedlce 2011, s. 26.

${ }^{4}$ P. Dec, Analiza ilościowa finansjeryzacji [w:] Finansjaryzacja gospodarki i jej wpływ na przedsiębiorstwa, red. nauk. A. Fierla, Warszawa 2017, s. 99.

5 A Fierla, A. Grygiel-Tomaszewska, Proces finansjaryzacji [w:] Finansjaryzacja gospodarki i jej wptyw..., s. 39-41.

${ }^{6}$ P.M. Sweezy, More (Or Less) on Globalization, „Monthly Review” 1997, no. 4, September, s. 3; J.B. Foster, Kryzys a finansyzacja kapitatu, "Le Monde diplomatigue" 2008, nr 7, monde-diplomatigue. P1/LM29/index.php?id=3 (dostęp: 10.12.2016 r.).

7 W.M. Orłowski, Dziesięć przyczyn kryzysu i ich analiza [w:] Globalny kryzys finansowy i jego konsekwencje w opiniach ekonomistów polskich, red. J. Szambelańczyk, Warszawa 2009, s. 7-15. 
trzynastokrotność światowego PKB. Za ten gwałtowny wzrost wartości w dużej mierze odpowiadał dynamiczny rozwój instrumentów pochodnych ${ }^{8}$.

Przejawy finansyzacji wpłynęły również na uczestników rynków finansowych. Zauważalny jest wzrost znaczenia instytucji finansowych, które zmuszone były do poszerzenia oferowanego asortymentu o nowe instrumenty bardziej skomplikowane od depozytów bankowych, a jednocześnie dające możliwość osiągnięcia potencjalnie większego dochodu. Takimi instrumentami są m. in. produkty strukturyzowane. Stanowią one zróżnicowaną grupę instrumentów, ich wspólną cechą jest istnienie określonego terminu zapadalności oraz gwarancji ochrony kapitału (nie zawsze pełnej), przy jednoczesnej możliwości osiągnięcia dodatkowych wysokich zysków, które nie są znane w momencie podejmowania decyzji o inwestycji. Pojawiły się po raz pierwszy na początku 2000 r. w formie lokat inwestycyjnych, a następnie jako tytuły uczestnictwa zamkniętego funduszu inwestycyjnego. Na rynek w Polsce zostały wprowadzone 25 sierpnia 2006 roku i od tamtej pory można zauważyć jego dynamiczny rozwój, przejawiający się nie tylko wzrostem obrotów, ale również pojawianiem nowych instrumentów9

Celem rozważań prowadzonych $\mathrm{w}$ artykule jest scharakteryzowanie finansyzacji, ale także ukazanie wpływu na rozwój rynku finansowego na przykładzie produktów strukturyzowanych jako innowacyjnych instrumentów finansowych w Polsce w latach 2009-2016.

\section{POJĘCIE, ŹRÓDŁA I SKUTKI FINANSYZACJI}

Finansyzację bardzo trudno jednoznacznie zinterpretować i dlatego istnieje wiele jej definicji o różnym stopniu szczegółowości i niejednakowym wyeksponowaniu konstytuujących ją czynników. Ponadto sam termin ,finansyzacja” powszechnie jeszcze się nie przyją $1^{10}$. Równolegle używa się takich pojęć, jak „finansjeryzacja”, „finansjalizacja”, „ufinansowienie” czy „kapitalizm finansowy” ${ }^{1}$. Pod tymi pojęciami kryje się samo zjawisko postępującej dominacji sektora finansowego w działalności jednostek gospodarujących i osób fizycznych ${ }^{12}$.

Zdaniem M. Ratajczaka finansyzacja powinna być rozpatrywana w wąskim i szerokim znaczeniu. W wąskim znaczeniu oznacza ona wzrost roli działalności finansowej w aktywności gospodarczej podmiotów niefinansowych, co prowadzi do tego, że w dochodach przedsiębiorstw o charakterze niefinansowym zwiększa się coraz bardziej udział dochodów z działalności finansowej kosztem dochodów z tradycyjnej działalności operacyjnej i inwestycyjnej, Natomiast w szerokim znaczeniu finansyzacja to proces autonomizacji sfery finansowej w relacji do sfery realnej i uzyskiwania nad nią nadrzędnej pozycji ${ }^{13}$.

\footnotetext{
8 Tamże, s. 49.

9 T. Kondrakiewicz., Rozwój rynku produktów ustrukturyzowanych na Giełdzie Papierów Wartościowych w Warszawie, Acta Universitatis Lodziensis Folia Oeconomica 2(301), 2014, s. 115.

${ }^{10}$ M. Ratajczak, Ekonomia i edukacja ekonomiczna w dobie finansyzacji gospodarki, „Ekonomista” 2014, s. 3.

11 J. Toporowski, Moja Polska i moje podejście do ekonomii, http;//www.pte.pl/314_ekonomiści_politycy_w_swiecie_pte.html (dostęp: 13.01.2018 r.).

12 A. Kamela-Sowińska, Od rachunkowości do opisu gospodarczego, „Zeszyty Teoretyczne Rachunkowości”, t. 77 (133), Warszawa 2014, s. 107-115.

${ }^{13}$ M. Ratajczak, Finansyzacja gospodarki, ,Ekonomista” nr 3, Warszawa 2012, s. 282-283.
} 
Podobnie proces finansyzacji określa E. Mączyńska ${ }^{14}$, stwierdzając, że jest to przyrost sektora finansowego w stosunku do realnego sektora wytwórczego, czyli sektora produkcji dóbr i usług. Dalej rozpatrując proces finansyzacji w ujęciu makroekonomicznym można zauważyć rosnącą rolę bodźców finansowych, rynków finansowych, podmiotów finansowych oraz instytucji finansowych w funkcjonowaniu zarówno narodowej, jak i globalnej gospodarki ${ }^{15}$.

Tabela 1. Ogólne i szczegółowe przyczyny finansyzacji

\begin{tabular}{|c|c|}
\hline Przyczyny ogólne & Przyczyny szczegółowe \\
\hline $\begin{array}{l}\text { Zmiany w strukturze } \\
\text { i działaniu rynków } \\
\text { finansowych }\end{array}$ & $\begin{array}{l}\text { - pojawienie się nowych, złożonych instrumentów finansowych (np. } \\
\text { instrumenty pochodne, produkty ustrukturyzowane), } \\
\text { - pojawienie się nowych typów pośredników finansowych, często nieob- } \\
\text { jętych nadzorem ostrożnościowym, } \\
\text { - wzrost roli i znaczenia finansowych inwestorów instytucjonalnych, } \\
\text { - nakładanie się poszczególnych segmentów rynku finansowego, } \\
\text { - deregulacja działalności finansowej, } \\
\text { - gwałtowany wzrost płynności rynków finansowych, } \\
\text { - postęp technologiczny i globalizacja rynków finansowych. }\end{array}$ \\
\hline $\begin{array}{l}\text { Rozwiązania z za- } \\
\text { kresu polityki spo- } \\
\text { łeczno-gospodarczej }\end{array}$ & $\begin{array}{l}\text { - polityka stymulowania globalizacji m.in. przez: zwiększenie swobody } \\
\text { przepływów kapitałowych, deregulację systemów finansowych, } \\
\text { - forsowanie koncepcji ograniczonego państwa, m.in. przez: odejście od } \\
\text { doktryny państwa dobrobytu i interwencjonizmu gospodarczego, pry- } \\
\text { watyzację, zmiany w systemach emerytalnych, } \\
\text { - wspieranie elastyczności rynku pracy, m.in. przez: osłabianie roli } \\
\text { związków zawodowych, ograniczenia wysokości płacy minimalnej, } \\
\text { zasiłków dla bezrobotnych, ochrony zatrudnienia, } \\
\text { - nastawienie w polityce gospodarczej na stabilność poziomu cen, m.in. } \\
\text { przez: skupienie się na procesach dezinflacji, prowadzenie polityki } \\
\text { wysokich realnych stóp procentowych. }\end{array}$ \\
\hline $\begin{array}{l}\text { Zmiany w zachowa- } \\
\text { niu przedsiębiorstw } \\
\text { niefinansowych }\end{array}$ & $\begin{array}{l}\text { - wprowadzanie koncepcji zarządzania wartością dla właścicieli, } \\
\text { - presja inwestorów na generowanie przez przedsiębiorstwa wysokich } \\
\text { stóp zwrotu w krótkim okresie, } \\
\text { - wykorzystywanie na szeroką skalę innowacji finansowych, co uzależ- } \\
\text { nia przedsiębiorstwa od instytucji finansowych i zwiększa ryzyko, } \\
\text { - wzrost roli właścicieli finansowych, nieangażujących się aktywnie } \\
\text { w długookresowy rozwój działalności przedsiębiorstw, } \\
\text { - prowadzenie polityki kapitałowej niezgodnej z teorią hierarchii źródeł } \\
\text { finansowania, polegające na upowszechnieniu się w przedsiębior- } \\
\text { stwach finansowania zewnętrznego, opartego głównie na mniej bez- } \\
\text { piecznym długu przeznaczanie wypracowanego kapitału wewnętrzne- } \\
\text { go na wypłaty dywidend lub wykupy akcji. }\end{array}$ \\
\hline
\end{tabular}

Źródło: opracowanie na podstawie: P. Marszałek, Finansyzacja - problemy i kontrowersje, Prace Naukowe Uniwersytetu Ekonomicznego we Wrocławiu, nr 247, Wrocław 2012, s. 223-225.

${ }^{14}$ E. Mączyńska, Dysfunkcje gospodarki w kontekście ekonomii kryzysu, „Zeszyty Naukowe Polskiego Towarzystwa Ekonomicznego" nr 9, Warszawa 2011, s. 57.

15 G. Epstein, Introduction, Financialization and the World Economy [w:] Financialization for the World Economy, ed. G. Epstein, E. Elgar, Northampton-Cheltenham 2005, s. 3. 
Na podstawie analizy definicji finansyzacji występujących w literaturze można stwierdzić, iż jej istotą jest narastająca dominacja sektora finansowego, w szczególności rynków kapitałowych i banków z ich wielorakimi spółkami zależnymi, nad sektorem przedsiębiorstw niefinansowych. Sfera finansowa staje się więc ważniejsza niż sfera realna. Generuje ona coraz więcej dochodów, a rynki finansowe wraz z działającymi na nich podmiotami finansowymi, które obracają instrumentami finansowymi, istotnie wpływają na decyzje podmiotów niefinansowych.

Złożoność i wielowymiarowość zjawiska finansyzacji sprawia, iż trudno wymienić jedną podstawową przyczynę jej powstania i rozwoju oraz jednoznacznie odróżnić, które z wymienionych procesów wywołują, a które towarzyszą zjawisku finansyzacji. Te ogólne przyczyny finansyzacji nazywane są wiodącymi kanałami jej rozpowszechniania, a pomiędzy nimi zachodzą interakcje oparte na mechanizmie sprzężenia zwrotnego. Do każdej z nich można ponadto dopisać listę przesłanek szczegółowych, co zostało zestawione $\mathrm{w}$ tabeli 1 . Finansyzacja zmienia także strukturę i funkcjonowanie rynków finansowych. Badania teoretyczne odnoszą się w tym przypadku m.in. do analizy wpływu finansyzacji (szczególnie dostępności do kredytów) na zmiany wyników makroekonomicznych i przebiegu cyklu koniunkturalnego ${ }^{16}$. Należy w tym miejscu zwrócić uwagę na hipotezę niestabilności finansowej H. Minsky' ego $^{17}$. Uważał on, że powstające „wyrafinowane" instytucje finansowe tworzą spekulacyjny popyt na pieniądz, zwiększają niepewność oraz podnoszą koszty pozyskania kapitału ${ }^{18}$. Sposób finansowania aktywów staje się więc nieobojętny dla stabilności finansowej, co wynika z angażowania się podmiotów gospodarczych w coraz bardziej ryzykowne formy finansowania działalności. W miarę rozpowszechniania się problemów z obsługą pozyskanych obcych źródeł finansowania spada w konsekwencji wartość rynkowa aktywów finansowych ${ }^{19}$.

W tabeli 2 przedstawiono systematykę wyodrębnionych w literaturze licznych konsekwencji finansyzacji. Przyjęto w tym celu ich umowny podział na występujące w sferze mikro- i makroekonomicznej. Ponadto należy zwrócić uwagę na fakt, że nie jest łatwo ustalić wszystkie zależności przyczynowo-skutkowe, co oznacza, że podane w tabeli 1 przyczyny i źródła finansyzacji mogą być także oceniane jako jej następstwa.

Podkreślenia wymaga fakt, że najważniejsze zmiany na rynkach finansowych dotyczące zjawiska finansyzacji polegały na pojawieniu się nowych, często bardzo skomplikowanych instrumentów pochodnych i produktów ustrukturyzowanych, co nie było możliwe bez rozwoju nowoczesnych technologii informatycznych. Równolegle na rynek finansowy gremialnie wchodzili nowi pośrednicy, często nieobjęci państwowym nadzorem finansowym. Następowała też deregulacja działalności finansowej, związana z wchodzeniem na krajowe rynki finansowe zagranicznych podmiotów finansowych, a szczególnie tzw. graczy globalnych. Ważnym motorem finansyzacji była też sekurytyzacja aktywów zamrożonych w bilansach podmiotów finansowych: należności z tytułu udzielonych kredytów hipotecznych, samochodowych i kartowych, a także z tytułu posiadanych obligacji

${ }^{16}$ G. Gołębiowski, P. Szczepanowski, Finansyzacja gospodarki krajów Europy Środkowo-Wschodniej, ,Ruch Prawniczy, Ekonomiczny i Socjologiczny” 4/2015, s. 202.

${ }^{17}$ H.P. Minsky, The financial instability hypothesis, „The Levy Economics Institute of Bard College Working Paper" nr 74/1992.

${ }_{18}$ P. Marszałek, Finansyzacja - problemy i kontrowersje, Prace Naukowe Uniwersytetu Ekonomicznego we Wrocławiu, nr 247, Wrocław 2012, s. 226-228.

${ }^{19}$ L.R. Wray, E. Tymoigne, Macroeconomics meets Hyman P. Minsky: the financial theory of investment, „Levy Economics Institute Working Paper”, nr 543/2008. 
skarbowych i korporacyjnych. Pozwoliła ona bankom i innym instytucjom finansowym nie tylko zwiększyć płynność i akcję kredytową, ale także przerzucić ryzyko na nabywców papierów wartościowych pochodzących z sekurytyzacji ${ }^{20}$.

Tabela 2. Mikro- i makroekonomiczne konsekwencje finansyzacji

\begin{tabular}{|c|c|}
\hline Skutki dla sfery mikroekonomicznej & Skutki dla sfery makroekonomicznej \\
\hline - skomplikowanie prowadzenia działalności & - skomplikowanie instytucji nadzoru finanso- \\
gospodarczej, & wego, \\
- uzależnienie kondycji poszczególnych pod- & - trudności w egzekwowaniu przestrzegania \\
miotów ekonomicznych od zmiennej sytua- & przez instytucje finansowe norm ostrożno- \\
cji na rynkach finansowych, & ściowych, \\
- utrudnienie wyboru właściwych źródeł & - uleganie dyktatowi rynków i instytucji finan- \\
finansowania i form lokowania oszczędno- & sowych, \\
ści na skutek wzrostu stopnia złożoności & - rosnący ciężar długu publicznego uzależnia- \\
rynków i operacji finansowych, & jący rządy od środków pozyskiwanych na \\
- podejmowanie coraz bardziej ryzykownych & rynkach finansowych, \\
przedsięwzięć ekonomicznych, & - pomoc publiczna instytucjom finansowym \\
- przyspieszenie tempa życia gospodarczego & popadającym w kłopoty finansowe, \\
intensyfikujące poczucie niepewności. & - wzmożona pokusa nadużyć (moral hazard), \\
& - utrudnione prowadzenie polityki pieniężnej \\
& z powodu zmian instytucjonalnych, co obniża \\
& jej skuteczność. \\
\hline
\end{tabular}

Źródło: opracowanie własne na podstawie: P. Marszałek, Finansyzacja..., s. 226-227.

\section{DYNAMIKA ROZWOJU RYNKU PRODUKTÓW STRUKTURYZOWANYCH NA GPW W POLSCE}

Dynamiczny rozwój rynku finansowego związany jest z przemianami, szybkim wprowadzaniem innowacyjnych instrumentów oraz nowoczesnych, coraz bardziej złożonych rozwiązań finansowych. Zmiany na rozważanym prze autorkę rynku są wynikiem zarówno pojawiania się nowych potrzeb w obszarze pozyskiwania kapitału, inwestowania oraz zarządzania ryzykiem, jak również poszukiwania coraz bardziej efektywnych metod osiągania zysków. Jednym z najbardziej znaczących i najszybciej rozwijających się obszarów światowego rynku finansowego w ostatnich latach był niewątpliwie segment produktów ustrukturyzowanych ${ }^{21}$.

Produkty strukturyzowane mogą przyjmować w Polsce różne formy prawne, takie jak lokaty bankowe, bankowe papiery wartościowe, obligacje strukturyzowane, certyfikaty funduszy inwestycyjnych zamkniętych, polisy ubezpieczeniowe. Każda z tych form podlega innym regulacjom prawnym i dzięki temu daje różne dodatkowe korzyści. Wiele z nich zapewnia całkowitą lub częściową ochronę zainwestowanego kapitału. Jednak obowiązuje ona wtedy, gdy produkt jest utrzymany do dnia jego wykupu. Obligacja strukturyzowana odpowiada złożeniu dwóch instrumentów finansowych: obligacji zerokuponowej oraz opcji kupna lub sprzedaży. Obligacja daje gwarancję otrzymania zainwesto-

20 E. Gostomski, Finansyzacja w gospodarce..., s. 303.

21 http://docplayer.pl/2104286-Rozwoj-rynku-produktow-strukturyzowanych-na-gieldzie-papierowwartosciowych-w-warszawie.html (dostep: 9.12.2017 r.). 
wanego kapitału, natomiast opcja posiada potencjał generowania zysków. Są one odpowiednimi produktami dla inwestorów z niską skłonnością do ryzyka, którzy obawiają się poniesienia straty lecz chcieliby lepiej zarobić niż na lokacie bankowej całkowitą lub częściową ochronę zainwestowanego kapitału. Jednak obowiązuje ona wtedy, gdy produkt jest utrzymany do dnia jego wykupu.

Od czasu powstania na GPW pierwszego produktu ustrukturyzowanego (obligacja strukturyzowana Deutsche Banku AG) nastąpił dynamiczny rozwój ilościowy rynku. Według stanu na koniec 2016 r. były notowane 784 produkty strukturyzowane (por. tabela 3). W ujęciu procentowym największy przyrost ich liczby miał miejsce w 2010 r., na koniec którego notowano ponad dwukrotnie więcej instrumentów tego typu niż rok wcześniej. Pierwsza połowa 2016 r. to okres intensywnego rozwoju rynku w sensie ilościowym, na koniec grudnia w obrocie na GPW znajdowało się 3553 produktów ustrukturyzowanych.

Tabela 3. Wolumen i wartość obrotów na rynku produktów strukturyzowanych na GPW w Warszawie w latach 2009-2016

\begin{tabular}{|l|c|c|c|c|c|c|c|c|}
\hline \multicolumn{1}{|c|}{$\begin{array}{c}\text { Nazwa } \\
\text { produktu }\end{array}$} & $\mathbf{2 0 0 9}$ & $\mathbf{2 0 1 0}$ & $\mathbf{2 0 1 1}$ & $\mathbf{2 0 1 2}$ & $\mathbf{2 0 1 3}$ & $\mathbf{2 0 1 4}$ & $\mathbf{2 0 1 5}$ & $\mathbf{2 0 1 6}$ \\
\hline $\begin{array}{l}\text { Liczba noto- } \\
\text { wanych serii } \\
\text { na koniec } \\
\text { roku }\end{array}$ & 70 & 148 & 206 & 343 & 557 & 748 & 702 & 784 \\
\hline $\begin{array}{l}\text { Wartość } \\
\text { obrotów } \\
\text { w całym roku } \\
\text { (tys. zł) }\end{array}$ & 156118 & 285188 & 350224 & 164332 & 280552 & 560501 & 721890 & 891694 \\
\hline $\begin{array}{l}\text { Srednie obro- } \\
\text { ty na sesję } \\
\text { (tys. zł) }\end{array}$ & 620 & 1127 & 1395 & 660 & 1136 & 2251 & 2876 & 3553 \\
\hline $\begin{array}{l}\text { Liczba trans- } \\
\text { akcji na sesję } \\
\text { tys. zł) }\end{array}$ & 66 & 93 & 127 & 77 & 135 & 234 & 334 & 506 \\
\hline $\begin{array}{l}\text { Srednia war- } \\
\text { tość transakcji } \\
\text { (tys. zł) }\end{array}$ & 9406 & 12146 & 10972 & 8578 & 8404 & 9600 & 8609 & 7015 \\
\hline
\end{tabular}

Źródło: opracowanie własne na podstawie www.gpw.pl (dostęp: 5.12.2017 r.).

O ile liczba notowanych produktów rosła systematycznie z roku na rok, to pod względem skali obrotów sytuacja w całym analizowanym okresie była zróżnicowana. Szczególnie dynamiczny był rok 2014, w którym to zanotowano wzrost wartości obrotów (około $100 \%)$. W następnych latach obroty w ujęciu ilościowym również wzrosły, ale proporcjonalnie ich przyrost był już znacznie mniejszy.

Na podkreślenie zasługuje również pierwsza połowa 2013 roku, ponieważ na GPW w Polsce notowane były także instrumenty ING Banku N.V., który na jednej sesji (debiut 12 czerwca) wprowadził na rynek aż 67 serii certyfikatów turbo. Najbardziej aktywny jest obecnie Raiffeisen Centrobank, który 17 lutego 2017 r. do obrotu giełdowego wprowadził 78 certyfikatów bez terminu wygaśnięcia (open-end). Nowe instrumenty są notowane na 
rynku równoległym w Systemie Animatora Rynku. Płynność certyfikatów będzie zapewniona przez animatora, którym jest Raiffeisen Centrobank z Wiednia. Certyfikaty faktor, czyli instrumenty ze stałą, określoną z góry na każdą sesję dźwignią, to instrumenty finansowe przeznaczone dla aktywnych inwestorów, szukających zysków na zmienności instrumentów bazowych. Dzięki tym produktom inwestorzy giełdowi mają możliwość zarabiania na zmianach cen najbardziej popularnych kontraktów terminowych na surowce, w tym na złoto, srebro i ropę naftową, jak również na indeksy lokalne i globalne, a także akcje polskich i zagranicznych spółek. Dodatkowym atutem debiutujących produktów jest możliwość zarabiania na wzrostach cen instrumentów bazowych (faktor long) i na ich spadkach (faktor short $)^{22}$.

Raiffeisen Centrobank AG (RCB) wspólnie z Giełdą Papierów Wartościowych w Warszawie (GPW) od lat rozwija rynek certyfikatów strukturyzowanych w Polsce. RCB jest obecnie największym emitentem certyfikatów na GPW, a w 2016 r. został po raz czwarty wyróżniony jako najlepszy emitent certyfikatów strukturyzowanych w krajach Europy Środkowo-Wschodniej. Co roku RCB analizuje potrzeby Inwestorów w Polsce i dostarcza produkty, które stanowią atrakcyjne rozwiązania inwestycyjne. Certyfikaty wyemitowane przez RCB od początku 2017 r. pozwalają zarabiać na wzrostach lub spadkach cen akcji wielu spółek zagranicznych takich jak Continental, Zalando, Adidas, czy Allianz. Ponadto RCB prowadzi szereg szkoleń mających na celu poszerzanie wiedzy na temat certyfikatów oraz rozwija sekcję edukacji produktowej ${ }^{23}$.

Ocena dynamiki i stanu rynku wymaga także analizy jego struktury ze względu na rodzaj notowanych produktów, które najbardziej ogólnie można podzielić na obligacje strukturyzowane i certyfikaty strukturyzowane. Biorąc pod uwagę ten podział, widać, że do rozwoju rynku przyczyniły się przede wszystkim certyfikaty. Chociaż pierwszym notowanym na polskiej giełdzie produktem strukturyzowanym były obligacje to w kolejnych latach w strukturze rynku zdecydowanie dominowały już certyfikaty. Jeśli chodzi o obligacje strukturyzowane to do 2011 roku następował stały, choć stosunkowo powolny wzrost ich ilości. Jednak ich udział w rynku w ujęciu procentowym systematycznie maleje i wynosi obecnie mniej niż 7\%. Warto zaznaczyć, że obecnie dość znaczny udział w strukturze instrumentów strukturyzowanych mają warranty opcyjne. Chociaż pojawiły się one na rynku dopiero w 2011 roku to już wówczas ich liczba ponad dwukrotnie przewyższała ilość serii obligacji strukturyzowanych.

Istotne znaczenie $\mathrm{w}$ analizie stanu rynku produktów strukturyzowanych ma nie tylko forma oferowanych instrumentów, ale także ich konstrukcja uwzględniająca rodzaj instrumentu bazowego czy poziom ochrony kapitału. Biorąc pod uwagę jako kryterium klasyfikacji instrument bazowy, na GPW można wyróżnić produkty strukturyzowane powiązane z trzema grupami, którymi są surowce (wraz z podstawowymi produktami rolnymi), indeksy lub ich koszyki oraz akcje. W dotychczasowym rozwoju rynku można wyodrębnić dwa okresy o odmiennej strukturze produktów ze względu na instrument bazowy. W pierwszym $\mathrm{z}$ nich zdecydowanie dominowały produkty skonstruowane w zależności od kształtowania się indeksów giełdowych lub ich koszyków do 2011 r. stanowiły one około 62\% (a więc prawie 2/3) wszystkich oferowanych na giełdzie. Relatywnie liczący się udział w rynku miały też produkty powiązane z akcjami (blisko 30\%),

\footnotetext{
${ }^{22} \mathrm{http} / / /$ biznes.interia.pl/gieldy/news/raiffeisen-centrobank-ag-poszerza-palete-produktow, 2478056,7581 (dostęp: 11.12.2017 r.)

23 Tamże.
} 
dla zdecydowanie niewielkiej części instrumentem bazowym były natomiast surowce (około 8\%). Od 2011 r. można obserwować istotne zmiany struktury produktów, polegające na spadku znaczenia produktów opartych na indeksach i ich koszykach, stosunkowo niewielkim wzroście udziału produktów powiązanych z akcjami przy jednoczesnym bardzo znaczącym wzroście udział u produktów opartych o różnego rodzaju surowce ${ }^{24}$.

\section{ZAKOŃCZENIE}

Podsumowując rozważania zawarte w niniejszym artykule należy zwrócić uwagę, że rynek produktów strukturyzowanych w Polsce jest stosunkowo młody. Dynamiczny rozwój instrumentów pochodnych tego rynku jest jednym z aspektów finansyzacji zarówno na świecie, jak i w Polsce. Podkreślenia wymaga fakt, iż nawet w sytuacji spadków na światowych rynkach finansowych liczba nowych emisji stale rosła. Systematycznie wzrasta też zróżnicowanie produktów, pojawiają się ich nowe formy i nowe instrumenty bazowe charakteryzujące się często wysokim poziomem złożoności. Łączna wartość instrumentów pochodnych obecnych na polskim rynku zwiększyła się w ciągu dziesięciu lat (miedzy 1998 r. a 2008 r.) z 72 bln USD do 683 bln USD, czyli niemal dziesięciokrotnie $^{25}$, zacieranie się granic między poszczególnymi segmentami rynku finansowego, czemu towarzyszyła postępująca do 2008 r. deregulacja, która m.in.. otworzyła przed bankami nowe możliwości działania na tym rynku; globalizowanie się rynku finansowego w okresie kilkunastu lat (miedzy 1990 r. a 2007 r.) globalne przepływy kapitałowe wzrosły ponad dziesięciokrotnie ${ }^{26}$, powstawanie konglomeratów łączących tradycyjną działalność depozytowo-kredytową z działalnością inwestycyjną (i spekulacyjną) oraz działalnością ubezpieczeniową, prowadzące do postępującej koncentracji w sektorze finansowym, czego skutkiem stał się wzrost wpływu największych podmiotów na funkcjonowanie całego rynku w 2013 r. na światowym rynku walutowym za 50\% obrotów odpowiadały tylko cztery instytucje finansowe ${ }^{27}$.

Na koniec pierwszej połowy 2016 roku w obrocie znajdowało się blisko 700 produktów strukturyzowanych, z czego tylko nieznaczną część stanowiły obligacje strukturyzowane, zaś zdecydowaną większość certyfikaty strukturyzowane ${ }^{28}$.

Przeprowadzona analiza pozwoliła na ukazanie finansyzacji i jej wpływu na rozwój polskiego rynku finansowego, co było celem tego opracowania. Wydaje się, że aby jednoznacznie wskazać przyczyny tego stanu rzeczy, autorka zauważa tu konieczność prowadzenia dalszych pogłębionych badań:

- w kategoriach naukowych koncepcja finansyzacji rynku finansowego wymaga dalszych studiów i badań, prowadzących do prób konstrukcji modeli czy teorii, a następnie ich testowania,

- niezależnie od tego, czy idea finansyzacji stanie się bardziej popularna, czy też wraz ze słabnięciem ostatniego kryzysu zainteresowanie tą koncepcją osłabnie, do-

${ }^{24}$ www.money.pl/gielda/gpw/certyfikaty (dostęp: 9.12.2017 r.).

25 W.M. Orłowski, Dziesięć przyczyn kryzysu i ich analiza....

${ }^{26} \mathrm{P}$. Sobolewski, Instrumenty pochodne na wspótczesnych rynkach finansowych, „Bank i Kredyt” 2009, nr 1, s.2.

${ }^{27}$ Euromoney FX Survey 2013, http://www.euromoney.com/Aricle/3200845/FX-survey-2013Deutsze-clings-on-despite-Citis-resurgence.html (dostęp: 12.12.2017 r.).

${ }^{28}$ T. Kondrakiewicz, Rozwój rynku produktów ustrukturyzowanych na Giełdzie Papierów Wartościowych w Warszawie, Acta Universitatis Lodziensis Folia Oeconomica 2(301), 2014, s. 13. 
brze by było, aby ekonomiści uwzględniali konsekwencje tego zjawiska i związaną z tym potrzebę integracji rozważań o sferze finansowej i sferze realnej,

- rozwój, jak i przyszły kształt rynku produktów strukturyzowanych będzie w dużej mierze determinowany przez zdarzenia i ogólną sytuację na światowych rynkach finansowych,

- dzięki nowoczesnym rozwiązaniom w ich konstrukcji stosowanym przez emitentów, wzrasta ich różnorodność, co ułatwia inwestorom dywersyfikację portfela i sprzyja rozwojowi rynku,

- zalety produktów strukturyzowanych powodują, że są one instrumentami o znamionach innowacyjności.

\section{Literatura}

1. Dec P., Analiza ilościowa finansjeryzacji [w:] Finansjaryzacja gospodarki i jej wptyw na przedsiębiorstwa, red. nauk. A. Fierla, Warszawa 2017.

2. Epstein G., Introduction, Financialization and the World Economy [w:] Financialization for the World Economy, ed. G. Epstein, E. Elgar, Northampton-Cheltenham 2005.

3. Fierla A., Grygiel-Tomaszewska A., Proces finansjaryzacji [w:] Finansjaryzacja gospodarki i jej wpływ na przedsiębiorstwa, red. nauk. A. Fierla, Warszawa 2017.

4. Husson M., Kapitalizm bez znieczulenia, Warszawa 2011.

5. Kamela-Sowińska A., Od rachunkowości do opisu gospodarczego, „Zeszyty Teoretyczne Rachunkowości”, t. 77/133, Stowarzyszenie Księgowych w Polsce, Warszawa 2014.

6. Kondrakiewicz T., Rozwój rynku produktów ustrukturyzowanych na Giełdzie Papierów Wartościowych $w$ Warszawie, Acta Universitatis Lodziensis Folia Oeconomica 2(301), 2014.

7. Marszałek P., Finansyzacja - problemy $i$ kontrowersje, Prace Naukowe Uniwersytetu Ekonomicznego we Wrocławiu, nr 247, Wrocław 2012.

8. Mączyńska E., Dysfunkcje gospodarki w kontekście ekonomii kryzysu, „Zeszyty Naukowe Polskiego Towarzystwa Ekonomicznego" nr 9, Warszawa 2011.

9. Minsky H.P., The financial instability hypothesis, „The Levy Economics Institute of Bard College Working Paper" 1992, nr 74.

10. Orłowski W.M., Dziesięć przyczyn kryzysu i ich analiza [w:] Globalny kryzys finansowy i jego konsekwencje $w$ opiniach ekonomistów polskich, red. J. Szambelańczyk, Związek Banków Polskich, Warszawa 2009.

11. Ratajczak M., Finansyzacja gospodarki, „Ekonomista” nr 3, PTE, Warszawa 2012.

12. Ratajczak M., Ekonomia i edukacja ekonomiczna $w$ dobie finansyzacji gospodarki, „Ekonomista” 2014.

13. Sobolewski P., Instrumenty pochodne na wspótczesnych rynkach finansowych, „Bank i Kredyt" 2009, nr 1.

14. Sweezy P.M., More (Or Less) on Globalization, „Monthly Review” 1997, No. 4, September.

15. Waściński T., Wójcik G., Struktura rynku finansowego w gospodarce światowej, Zeszyty Naukowe Uniwersytetu Przyrodniczo-Humanistycznego, nr 88, Seria Administracja i Zarządzanie (15), Siedlce 2011.

16. Wiśniewski P., Nowe miary finansjalizacji [w:] Rozwój nauki o finansach. Stan obecny i pożądane kierunki jej ewolucji, red. J. Ostaszewski, E. Kosycarz, Szkoła Główna Handlowa w Warszawie, Warszawa 2014. 
17. Wray L.R., Ymoigne E.T., Macroeconomics meets Hyman P. Minsky: the financial theory of investment, „Levy Economics Institute Working Paper”, nr 543/2008.

18. Wrzesiński M., Finansjalizacja gospodarki - fakty czy mity? [w:] Rozwój nauki o finansach. Stan obecny i pożadane kierunki jej ewolucji, red. J. Ostaszewski, E. Kosycarz, Szkoła Główna Handlowa w Warszawie, Warszawa 2014.

\title{
Netografia
}

1. Euromoney FX Survey 2013, http://www.euromoney.com/Aricle/3200845/FX-survey2013-Deutsze-clings-on-despite-Citis-resurgence.html

2. Foster J.B., Kryzys a finansyzacja kapitatu, "Le Monde diplomatigue" 2008, nr 7, mondediplomatigue. Pl/LM29/index.php?id=3

3. http://biznes.interia.pl/gieldy/news/raiffeisen-centrobank-ag-poszerza-palete-produktow

4. http://docplayer.pl/2104286-Rozwoj-rynku-produktow-strukturyzowanych-na-gieldziepapierow-wartosciowych-w-warszawie.html

5. Toporowski J., Moja Polska $i$ moje podejście do ekonomii, http;//www.pte.pl/ 314_ekonomiści_politycy_w_swiecie_pte.html

6. www.money.pl/gielda/gpw/certyfikaty

\section{THE IMPACT OF FINANCIALIZATION ON DEVELOPMENT OF THE FINANCIAL MARKET ON THE EXAMPLE OF STRUCTURED PRODUCTS IN POLAND IN YEARS 2006-2016}

\begin{abstract}
The aim of this paper is not only to characterise financialization but to present its influence on development of the financial market on the example of structured products as innovative financial instruments in Poland in years 2009-2016. Even though different studies do not omit political, cultural and social circumstances constituting the basis of enterprise financialization, the English-language literature, which is dominant in this field, focuses mainly on describing the close relationship between the activity of institutional investors and the scale of financial accumulation. First of all, it has been shown that the increased degree of financialization is connected with the pressure from the "impatient" institutional investors, who are more interested in short-term company profits and current consumption than in obtaining better results from a business activity in the long run, conditioned by effective allocation of the internal capital. This phenomenon is regarded as the main driving factor for the tendency to seek the maximum rate of return from the invested capital at the lowest risk, which consequently constitutes the fundamental imperative of SHV concept. Financialization understood as dominance of the finance sector over the real sector, which is the most noticeable in the USA, was one of the major causes of the global financial crisis. Basing on Polish and foreign source literature, as well as statistical data, the author outlines the main causes, intensity and consequences of financialization in the Polish financial market.
\end{abstract}

Keywords: financialization, structured products, financial instruments, financial market.

DOI: 10.7862/rz.2018.mmr.11

Tekst złożono $w$ redakcji: marzec $2018 r$.

Przyjęto do druku: marzec $2018 \mathrm{r}$. 
